\title{
Drimia jeevae (Asparagaceae), a new species from southern Western Ghats of Tamil Nadu, India
}

\author{
S. Karuppusamy \& V. Ravichandran \\ Center for Botanical Research, Department of Botany, \\ The Madura College, Madurai - 625011, Tamil Nadu, India \\ ravichandran725@gmail.com
}

\begin{abstract}
Drimia jeevae Karupp. \& V.Ravich. (Asparagaceae) is described as a new species from the Alamparai Hills, Kanyakumari District, which is a part of the southern Western Ghats of Tamil Nadu, India. A detailed description, illustration, phenology, and relevant ecological notes are provided, along with a comparison to the morphologically similar species Drimia razii Ansari and Drimia wightii Lakshmin.
\end{abstract}

Keywords. Alamparai Hills, Drimia razii, Drimia wightii, Kanyakumari, plant endemism

\section{Introduction}

Drimia Jacq. ex Willd., with 91 accepted species (POWO, 2019), belongs to the family Asparagaceae and is for the most part dispersed in Africa, Madagascar, the Mediterranean Basin and in Asia from the Arabian Peninsula through Southwest Asia to the Indian Subcontinent and continental Southeast Asia (POWO, 2019; Saha \& Jha, 2019; Yadav et al., 2019). Species diversity is highest in Africa. Currently, a total of eight species of Drimia are recorded for India, of which all except D. indica (Roxb.) Jessop are endemic (Lekhak et al., 2014; Saha \& Jha, 2019; Yadav et al., 2019). However, the taxonomic delimitation of the genus is ill-defined. Roxburgh (1832) included two Indian species (Scilla coromandeliana Roxb. and S. indica Roxb.) in the genus Scilla L. Later, Hooker (1892) added five species in Urginea Steinh., a genus which was synonymised into Drimia by Jessop (1977). However, many Indian taxonomists have not accepted the synonymisation of these two genera (Deb \& Dasgupta, 1981; Yadav \& Dixit, 1990). Furthermore, Speta (2001) proposed a new generic name Indurgia Speta for Indian Drimia. Several morpho-taxonomic revisions of Indian Drimia have been published but morphological characters alone may not be sufficient to delimit the Indian Drimia due to vegetative similarities among the species (Lekhak et al., 2014). Cytotaxonomic, karyological, palynological and molecular studies have also been undertaken, along with interspecific hybridisation studies, in attempts to better understand species delimitations and relationships (Lekhak et al., 2017; Yadav et al., 2019). However, all of these earlier studies have concluded that the interspecific relationships of Indian Drimia still remain unclear (Saha \& Jha, 2019). 


\section{Materials and methods}

During a botanical exploration in 2012 in the Alamparai Hills in the Kanyakumari District of the southern Western Ghats, Tamil Nadu, India, the authors came across unusual specimens of a Drimia species. Critical examination and perusal of the relevant literature (Hooker, 1892; Deb \& Dasgupta, 1974, 1981; Ansari, 1981; Lakshminarasimhan, 2003; Yadav et al., 2016, 2019), together with consultation of images of type specimens at BLAT, BSI, CAL and K (herbarium acronyms follow Thiers, continuously updated), led to the conclusion that the specimens do not belong to any known species. We therefore conclude it is a new species and describe it here.

\section{Taxonomic treatment}

\section{Drimia jeevae Karupp. \& V.Ravich., sp. nov.}

The new species is closely allied to Drimia razii Ansari, but it differs in the bulb having a neck to $4 \mathrm{~cm}$ long (vs bulb without neck in $D$. razii), floral bracts persistent, ovate-lanceolate (vs floral bracts caducous, deltoid), inflorescence 10-flowered (vs inflorescence 15-flowered), and tepals rounded at apex, yellowish green (vs tepals obtuse at apex, dull brownish). It is also allied to Drimia wightii Lakshmin. but can be distinguished by the bulb being ovoid to conical (vs bulb ovoid to subglobose), leaves linear, dry when flowering (vs leaves linear-lanceolate, present when flowering), floral bracts persistent, ovate-lanceolate (vs floral bracts caducous, deltoid), tepals ellipticoblong, rounded at apex, yellowish green (vs tepals lanceolate, acute at apex, brownish green), and capsule oblong-elliptic, 3-winged (vs capsule subglobose, angles not winged). - TYPE: India, Tamil Nadu, Kanyakumari District, Alamparai Hills, 600 m, 9 March 2012, S. Karuppusamy \& V. Ravichandran 874 (holotype MH; isotypes Sri Ganesan Herbarium, Department of Botany, The Madura College, Madurai). (Fig. 1; Table 1).

Herb; bulbs 4-6 $\times 3-4 \mathrm{~cm}$, ovoid to conical with neck to $4 \mathrm{~cm}$ long, scales dull white. Leaves 3-4, dry when flowering, linear, canaliculate, 8-10 $\times 0.4-0.8 \mathrm{~cm}$, apex acute, glabrous. Scape solitary, slender, 10-15 cm long, cylindrical, greenish yellow, glabrous. Inflorescence a raceme, dense in bud, lax at anthesis, 8-10 cm long, 10-flowered; bracts persistent, ovate-lanceolate, c. $5 \mathrm{~mm}$ long, base auriculate, apex acute; pedicels erect, 4-7 mm long, cylindrical, stout, brownish green, glabrous. Flowers diurnal, yellowish green; tepals connate at base, apically spreading, not reflexed, single-veined, veins greenish yellow, outer tepals elliptic-oblong, 6-8 $\times 1.5-3 \mathrm{~mm}$, inner tepals similar to the outer ones, equal, margins entire, apex rounded to slightly emarginate. Stamens filamentose; filaments gradually tapering, up to $3 \mathrm{~mm}$ long, cylindrical, glabrous, yellowish white; anthers dorsifixed, 1-2 mm long, bright yellow. Ovary ovoidoblong, $1-2 \times 0.5-1 \mathrm{~cm}$, green; style obconic, 5-8 mm long, persistent in fruit; stigma subglobose, trilobed, greenish or white, papillose. Capsule oblong-elliptic, 0.9-1.5 $\times$ 0.5-1 cm, 3-winged, greenish, wing margins purplish brown, glabrous. Seeds broadly ovoid, $0.2-0.5 \times 0.2-0.3 \mathrm{~mm}$, black, flat, winged, glabrous. 


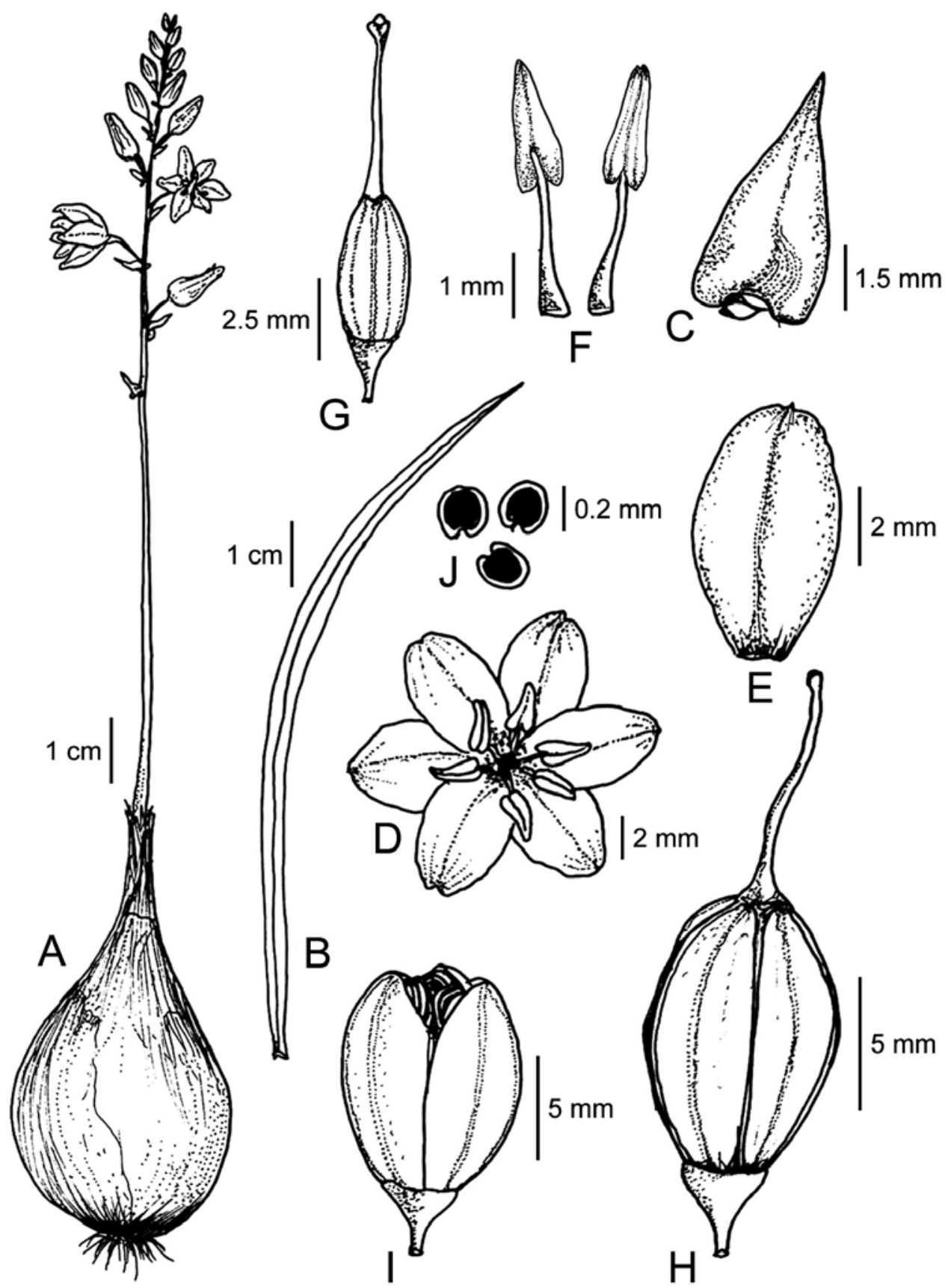

Fig. 1. Drimia jeevae Karupp. \& V.Ravich. A. Habit. B. Leaf. C. Bract. D. Flower, front view. E. Perianth. F. Stamens. G. Pistil. H. Fruit. I. Dehiscing fruit. J. Seeds. From Karuppusamy \& Ravichandran 874 . Drawn by S. Karuppusamy. 
Table 1. Selected diagnostic differences between Drimia jeevae and the morphologically similar species D. razii and D. wightii.

\begin{tabular}{|c|c|c|c|}
\hline Character & Drimia razii & Drimia wightii & Drimia jeevae \\
\hline Bulb & $\begin{array}{l}\text { Ovoid to subglobose, } \\
\text { without neck }\end{array}$ & $\begin{array}{l}\text { Ovoid to subglobose, } \\
\text { neck } 2-4 \mathrm{~cm} \text { long }\end{array}$ & $\begin{array}{l}\text { Ovoid to conical, } \\
\text { neck to } 4 \mathrm{~cm} \text { long }\end{array}$ \\
\hline Leaves & $\begin{array}{l}\text { Linear, 4-9, dry } \\
\text { when flowering }\end{array}$ & $\begin{array}{l}\text { Linear-lanceolate, } 2- \\
5 \text {, present when } \\
\text { flowering }\end{array}$ & $\begin{array}{l}\text { Linear, 3-4, dry } \\
\text { when flowering }\end{array}$ \\
\hline Scape & $\begin{array}{l}\text { Solitary, up to } 20 \mathrm{~cm} \\
\text { long, greenish brown }\end{array}$ & $\begin{array}{l}\text { Solitary, rarely two, } \\
\text { up to } 15 \mathrm{~cm} \text { long, } \\
\text { greenish brown }\end{array}$ & $\begin{array}{l}\text { Solitary, up to } 15 \mathrm{~cm} \\
\text { long, greenish } \\
\text { yellow }\end{array}$ \\
\hline Floral bracts & Caducous, deltoid & Caducous, deltoid & $\begin{array}{l}\text { Persistent, ovate- } \\
\text { lanceolate }\end{array}$ \\
\hline Inflorescence & $\begin{array}{l}\text { Lax, up to } 15- \\
\text { flowered }\end{array}$ & $\begin{array}{l}\text { Compact, up to } 10- \\
\text { flowered }\end{array}$ & Lax, 10-flowered \\
\hline Tepals & $\begin{array}{l}\text { Elliptic-oblong, } \\
\text { slightly unequal, } \\
\text { obtuse at apex, dull } \\
\text { brownish }\end{array}$ & $\begin{array}{l}\text { Lanceolate, equal, } \\
\text { acute at apex, } \\
\text { brownish green }\end{array}$ & $\begin{array}{l}\text { Elliptic-oblong, } \\
\text { equal, rounded at } \\
\text { apex, yellowish } \\
\text { green }\end{array}$ \\
\hline Capsule & $\begin{array}{l}\text { Ovoid-elliptic, 3- } \\
\text { winged }\end{array}$ & $\begin{array}{l}\text { Subglobose, angles } \\
\text { not winged }\end{array}$ & $\begin{array}{l}\text { Oblong-elliptic, 3- } \\
\text { winged }\end{array}$ \\
\hline
\end{tabular}

Distribution and ecology. Endemic to the southernmost part of the Western Ghats in Tamil Nadu, on rocky hill slopes below $700 \mathrm{~m}$ elevation. The associated plants are Henckelia gambleana (C.E.C.Fisch.) A.Weber \& B.L.Burtt (Gesneriaceae), Decalepis arayalpathra (J.Joseph \& V.Chandras.) Venter(Apocynaceae), Oldenlandia corymbosa L. var. corymbosa (Rubiaceae), Arundina graminifolia (D.Don) Hochr. (Orchidaceae), Cymbopogon martini (Roxb.) Will.Watson (Poaceae), Themeda cymbaria Hack. (Poaceae), Tripogon sp. (Poaceae) and Phyllocephalum scabridum (DC.) K.Kirkman (Asteraceae).

Phenology. Flowering from February to March and fruiting from March to May (flowers are diurnal, opening in the morning and fading by afternoon).

Etymology. The specific epithet honours Dr Solomon Jeeva, Assistant Professor, Department of Botany, Scott Christian College, Nagercoil, for helping the authors to locate the species. 
Provisional IUCN conservation assessment. Further work is necessary to establish the distribution and population size of Drimia jeevae and until this can occur, it is assessed here as Data Deficient (DD) (IUCN Standards and Petitions Committee, 2019).

ACKNOWLEDGEMENTS. The authors are thankful to the Head Office, Botanical Survey of India, Southern Regional Centre Coimbatore for permitting us to consult the herbaria and library. We acknowledge the curators of BLAT, BSI, CAL and K for providing digital images of type specimens for the study. We are especially grateful to Dr S. Jeeva, Assistant Professor, Department of Botany, Scott Christian College, Nagercoil for helping to locate the species. We are grateful to two anonymous reviewers for improving the manuscript.

\section{References}

Ansari, M.Y. (1981). Drimia razii sp. nov. (Liliaceae) from Maharashtra, India. J. Bombay Nat. Hist. Soc. 78(3): 572-574.

Deb, D.B. \& Dasgupta, S. (1974). Revision of the genus Urginea Steinhill (Liliaceae) in India. Bull. Bot. Surv. India 16: 116-124.

Deb, D.B. \& Dasgupta, S. (1981). Fascicles of Flora of India, fasc. 7, Liliaceae: Tribe-Scillae. Kolkata: Botanical Survey of India, Howrah.

Hooker, J.D. (1892). Urginea. In: The Flora of British India, vol. 6, pp. 347-348. London: L. Reeve \& Co.

IUCN Standards and Petitions Subcommittee (2019). Guidelines for Using the IUCN Red List Categories and Criteria. Version 14. Prepared by the Standards and Petitions Committee. Available from: http://www.iucnredlist.org/documents/RedListGuidelines.pdf.

Jessop, J.P. (1977). Studies in the bulbous Liliaceae in South Africa: 7. The taxonomy of Drimia and certain allied genera. J. S. African Bot. 43: 265-319.

Lakshminarasimhan, P. (2003). Anew name for Drimia congesta (Wight) Stearn(Hyacinthaceae). Kew Bull. 58: 507-508.

Lekhak, M.M., Adsul, A.A. \& Yadav, S.R. (2014). Cytotaxonomical studies on Drimia nagarjunae and a review on the taxonomy of Indian species of Drimia. The Nucleus 57(2): 99-103.

Lekhak, M.M., Yadav, P.B., \& Yadav, S.R. (2017). Cytogenetic studies in Indian Drimia Jacq. (Urgineoideae: Hyacinthaceae). In: Bhat, T.A. \& Wani, A.A. (eds) Chromosome Structure and Aberrations, pp. 141-165. India: Springer.

POWO (2019). Plants of the World Online. Facilitated by the Royal Botanic Gardens, Kew. Published on the Internet; http://www.plantsoftheworldonline.org. Accessed $07 \mathrm{Jul}$. 2020.

Roxburgh, W. (1832). Scilla. In: Flora Indica; or, Descriptions of Indian Plants, vol. 2, pp. 147-148. Calcutta: W. Thacker \& Co.

Saha, P.S. \& Jha, S.A. (2019). A molecular phylogeny of the genus Drimia (Asparagaceae: Scilloideae: Urgineeae) in India inferred from non-coding chloroplast and nuclear ribosomal DNA sequences. Sci. Rep. 9: 7563.

Septa, F. (2001). Die echte und die falsche Meerzwiebel: Charybdis Speta und Stellarioides Medicus (Hyacinthaceae), mit Neukombinationen und Neubeschreibungen im Anhang. Stapfia 75: 139-176. 
Thiers, B. (continuously updated). Index Herbariorum: A global directory of public herbaria and associated staff. New York Botanical Garden's Virtual Herbarium. http://sweetgum. nybg.org/science/ih. Accessed 20 Jan. 2021.

Yadav, P.B., Lekhak, M.M. \& Yadav, S.R. (2016). Typifications in Drimia with notes on the identity of D. wightii (Asparagaceae, Scilloideae). Phytotaxa 289: 256-262.

Yadav, P.B., Manning, J.C., Yadav, S.R. \& Lekhak, M.M. (2019). A cytotaxonomic revision of Drimia Jacq. (Hyacinthaceae: Urgineoideae) in India. S. African J. Bot. 123: 62-86.

Yadav, S.R. \& Dixit, G.B. (1990). Cytotaxonomical Studies in Indian Urginea Steinhill Species. Cytologia 55: 293-300. 